\title{
REKONSTRUKSI GAGASAN METODE MONTESSORI DALAM BIMBINGAN DAN KONSELING ANAK USIA DINI
}

\author{
Cato, Muhammad Alim Kahfi
}

Institut Agama Islam Bakti Negara (IBN) Tegal

\begin{abstract}
Abstrak
Bimbingan dan konseling untuk anak usia dini merupakan upaya memfasilitasi individu (anak) yang sedang tumbuh dan berkembang, dengan harapan agar kelak potensinya mampu berkembang dan mencapai tugas-tugas perkembangan secara optimal. Dari beberapa tokoh barat modern yang memiliki pengaruh besar terhadap perkembangan Pendidikan Anak Usia Dini di dunia ini adalah Maria Montessori. Bagaimana gagasannya dalam pengembangan metode bimbingan dan konseling untuk anak usia dini. Penelitian ini menggunakan jenis penelitian kepustakaan (library research). Prinsip-prinsip metode Montessori dalam bimbingan dan konseling bagi anak usia dini secara umum adalah bahwa anak dilihat sebagai individu yang harus dikembangkan potensinya seoptimal mungkin dalam lingkungan si anak. Kita sebagai orang dewasa tidak bisa menyepelekan dan meremehkan kemampuan anak, sehingga anak memilki hak untuk belajar sesuai dengan cara dan metode yang diinginkannya. Guru dan pembimbing anak usia dini harus mampu memfasilitasi anak belajar sesuai dengan metode, jenis main dan kegiatan yang diinginkannya.
\end{abstract}

Kata kunci : metode montessori, perkembangan anak, bimbingan dan konseling anak

\begin{abstract}
Guidance and counseling for early childhood is an effort to facilitate individuals who are growing and developing, in the hope that later their potential is able to develop and achieve optimal developmental tasks. Of the few modern western figures who have had a major influence on the development of Early Childhood Education in this world is Maria Montessori. How is the idea in the development of guidance and counseling methods for early childhood. This research uses a type of library research. The principles of the Montessori method of guidance and counseling for early childhood in general is that the child is seen as an individual who must develop his or her potential as optimally as possible in the child's environment. We as adults cannot underestimate and underestimate the child's ability, so that children have the right to learn in accordance with the ways and methods they want. Teachers and early childhood guides should be able to facilitate children to learn in accordance with the methods, types of play and activities they want.
\end{abstract}

Key: Montessori method, child development, child guidance and counseling 


\section{PENDAHULUAN}

Bimbingan dan Konseling adalah pelayanan bantuan untuk peserta didik. Baik secara perorangan maupun kelompok agar mandiri dan bisa berkembang secara optimal, dalam bimbingan pribadi, sosial, belajar maupun karir melalui berbagai jenis layanan dan kegiatan pendukung berdasarkan norma-norma yang berlaku (SK Mendikbud No. 025/D/1995). Selain itu Bimbingan dan Konseling merupakan upaya proaktif dan sistematik dalam memfasilitasi individu mencapai tingkat perkembangan yang optimal, pegembangan perilaku yang efekyif, pengembangan lingkungan dan peningkatan fungsi atau manfaat individu dalam lingkungannya. Semua perubahan perilaku tersebut merupakan proses perkembangan individu, yakni proses interaksi antara individu dengan lingkungan melalui interaksi yang sehat dan produktif (Daryanto dan Mohammad Farid, 2015: 23).

Penyelenggaraan bimbingan dan konseling untuk anak usia dini merupakan upaya memfasilitasi individu (anak) yang sedang tumbuh dan berkembang segala potensi dan aspek perkembangannya, agar kelak potensinya mampu berkembang atau mencapai tugas-tugas perkembangan secara optimal. Untuk mencapai kematangan tersebut anak memerlukan bimbingan karena sebagai individu yang masih berada di lembaga pendidikan prasekolah, anak belum memiliki pemahaman ataupun wawasan tentang dirinya dan lingkungannya, termasuk juga pengalaman dalam menentukan arah kehidupannya.

Pertumbuhan fisik memang mempengaruhi perkembangan psikis, misalnya bertambahnya fungsi otak memungkinkan anak dapat tertawa, berjalan, berbicara, dan sebagainya. Perkembangan juga berkaitan dengan belajar khususnya mengenai isi proses perkembangan. Apa yang berkembang berkaitan dengan perilaku belajar. Selain itu bagaimana hal sesuatu dipelajari, misalnya apakah melalui memorisasi (menghafalkan) atau mengerti hubungan, ikut menentukan perkembangan. Dengan demikian perkembangan dapat diartikan sebagai proses yang kekal dan tetap yang menuju kearah suatu organisasi pada tingkat integrasi yang lebih tinggi, berdasarkan pertumbuhan, pemasakan dan belajar (Monks, 2006: 2).

Disisi lain, dalam proses tumbuh dan berkembang menuju kematangan dan kemandirian tersebut anak juga tidak selamanya berlangsung secara mulus serta terlepas dari sejumlah masalah dan hambatan. Mereka seringkali menemui banyak kendala sehingga proses pertumbuhan dan perkembangannya tidak selalu berjalan linier sesuai yang diharapkan. Untuk itu guru dan orang tua sebagai individu yang paling dekat dengan anak perlu memahami dan membantu membimbing anak agar berbagai aspek perkembangan dapat tumbuh dan berkembang secara optimal.

Layanan bimbingan di lembaga pendidikan anak usia dini merupakan bagian dan penunjang yang tak terpisahkan dari keseluruhan kegiatan pendidikan di lembaga pendidikan prasekolah dan mencakup seluruh tujuan dan fungsi bimbingan. Dilihat dari tujuan dan materinya, ruang lingkup layanan bimbingan pada jenjang PAUD mengutamakan penekanan pada kegiatan: 1). Bimbingan Pribadi-Sosial, 2). Bimbingan Belajar, 3). Bimbingan Karier. Selain itu bentuk layanan bimbingan dan konseling bagi anak usia dini diantaranya adalah: layanan pengumpulan data, layanan informasi, layanan konseling, layananan penempatan, serta layananan evaluasi dan tindak lanjut (Fiah, 2019: 24-25).

Dalam melaksanakan bimbingan belajar anak usia dini ada beberapa metode pembelajaran yang seharusnya dilakukan oleh guru, diantaranya adalah: tanya jawab, demonstrasi, bercakap-cakap dan diskusi kelompok. Para guru diharuskan berusaha untuk tidak menerangkan langsung ke anak, melainkan guru yang lebih banyak bertanya kepada anak (Kahfi, 2020: 82). Pada prakteknya masih banyak ditemukan guru belum melaksanakan pembelajaran saintifik, masih banyak dengan metode ceramah dan pembelajaran yang berpusat pada guru. Selain itu masih banyak ditemukan penggunaan Lembar Kerja Anak (LKA) oleh guru dalam melaksanakan bimbingan belajar kepada anak. Sehingga perlu pemahaman bersama dan satu pandangan yang holistik mengenai Bimbingan dan Konseling Pada Anak Usia Dini.

Dari beberapa tokoh barat modern yang memiliki pengaruh besar terhadap perkembangan Pendidikan Anak Usia Dini di dunia ini adalah Maria Montessori. Hasil kajian dan penelitiannya dijadikan sebuah pendekatan bagi lembaga-lembaga pendidikan bahkan sampai pada taraf Internasional. Dari sekian banyak tokoh pendidikan anak, hanya Montessori yang mencurahkan hampir keseluruhan hidupnya untuk anak-anak. Siapa sebenarnya Maria Montessori itu, lalu bagaimana gagasan-gagasannya dalam pengembangan dasar-dasar metode bimbingan dan konseling untuk anak usia dini, semuanya akan 
penulis bahas dalam penelitian ini. Sebagai kelompok akademisi kita patut mengapresiasi secara objektif gagasan seseorang, walaupun kita harus melihat secara objektif pula dalam menggunakan gagasangagasan tersebut dengan mempertimbangkan banyak aspek yang saling berkaitan.

\section{METODE}

Penelitian ini menggunakan jenis penelitian kepustakaan (library research), yaitu penelitian yang dalam pengumpulan datanya dengan cara menghimpun dari buku-buku, majalah, paper, maupun ensiklopedi yang ada relevansinya dengan penelitian ini. Sifat dari penelitian pustaka ini adalah deskriptifanalitis, dimana peneliti mencoba menyajikan dan menggambarkan secara objektif tentang gagasan yang sebenarnya dari objek yang diteliti untuk kemudian diinterpretasikan dan dibandingkan. Alasan utama peneliti menggunakan jenis penelitian ini adalah karena peneliti akan mendeskripsikan gagasan dari tulisan-tulisan karya Maria Montessori atau karya dari tokoh-tokoh lain yang menjelaskan gagasan Maria Montessori, yang kemudian nantinya akan peneliti rekonstruksi gagasan tersebut dalam Konsep Dasar Bimbingan dan Konseling Anak Usia Dini.

Objek dalam penelitian ini adalah buku karya tulis Prof. Dr. Maria Montessori yaitu: Metode Montessori, Terj. Ahmad Lintang Lazuardi, Yogyakarta: Pustaka Pelajar, 2013; buku karya tulis Agustina Prasetyo yaitu: Sejarah Pendekatan Montessori, Yogyakarta: KANISIUS, 2013; buku karya tulis Dr. Rifda El Fiah, M.Pd yaitu: Bimbingan dan Konseling Anak Usia Dini, Cet-2, Depok: Rajawali Pers, 2019; serta buku dan karya tulis lain yang berkaitan. Dalam mengumpulkan data peneliti menggunakan teknik dokumentasi. Teknik ini merupakan penelaahan terhadap referensi-referensi yang berhubungan dengan fokus permasalahan penelitian. Dalam penelitian kualitatif studi dokumentasi, peneliti dapat mencari dan mengumpulkan data-data teks atau image (Iskandar, 2008: 219). Setelah data yang dibutuhkan dikumpulkan dengan teknik dokumentasi, kemudian peneliti mengambil kesimpulan melalui teknik content analysis dengan metode deduktifinduktif.

\section{HASIL DAN PEMBAHASAN}

\section{Biografi Maria Montessori}

Seorang perempuan berkebangsaan Italia yang memiliki nama lengkap Maria Montessori dilahirkan pada tanggal 31 Agustus 1870 di kota Chiaravalle, provinsi Ancona, Italia Utara. Ayah Maria Alessandro Montessori adalah tentara pejuang yang mendukung persatuan Italia dan memiliki pemikiran sangat tradisional serta militan. Renilde Stoppani, ibu Maria Montessori berasal dari keluarga kaya dan berpendidikan tinggi. Menururt Kramer sebagaimana dikutip oleh Agustina Prasetyo Magini, Renilde Stoppani disebut sebagai "wanita dalam era transisi" (Magini, 2013: 9).

Selepas dari militer, Alessandro menjadi pegawai negeri. Setelah berhasil membantu persatuan Italia, Alessandro diangkat sebagai karyawan kepausan dan bekerja sebagai akuntan di departermen keuangan. Namun pada tahun 1853, Alessandro mengundurkan diri dan memilih menjadi pengawas atau "inspektur" perusahaan garam dan tembakau "Comachio e Cervia" yang masih berada dibawah kantor kementrian keuangan. Sebagai inspektur, Alessandro sering ditugaskan ke berbagai tempat. Pada tahun 1865 Alessandro ditugaskan di Chiaravalle, yang kemudian pada saat itulah ia bertemu dengan Renilde Stoppani seorang wanita cantik keturunan bangsawan.

Alessandro dan Renilde menikah pada musim semi tahun 1866. Saat itu Alessandro berusia 33 tahun, tetapi sudah memiliki pekerjaan dengan jabatan tinggi. Setelah menikah Alessandro ditugaskan ke Venice. Pada tahun 1869, mereka kembali Chiarvalle. Setahun kemudian, lahirlah Maria. Mengingat jasa alessandro Montessori yang sangat besar terhadap pemerintah Italia, ia mendapatkan anugerah jasa "Cavaliere" yang setingkat dengan gelar kebangsawanan dari kerajaan Inggris pada tahun 1880. Saat itu maria masih berusia 10 tahun dan Alessandro berusia 48 tahun.

Renilde stoppani, meskipun mengikuti pola hidup tradisional dengan mendedikasikan hidupnya sebagai ibu rumah tangga, namun ia tetap mendukung ambisi dan keinginan anaknya dalam melawan arus stereotipe wanita pada masa itu. Renilde sangat liberal dan mengagumi sepupunya, Antonio Stoppani. Dia adalah pakar di bidang ilmu Bumi dan Paleontologi (Ilmu Fosil). Sumbangan Antonio 
adalah pandangan positif tentang ilmu bumi dan fosil yang saat itu sedikit bertentangan dengan dogma gereja.

Maria tumbuh dan berkembang diantara orang-orang berjiwa patriotik dan sangat terbuka terhadap kemajuan. Namun jika ia sendiri tidak memiliki krakter istimewa dari dalam dirinya, tentu ia tidak akan memiliki kepekaan terhadap problematika sosial yang ada saat itu. Maria dibesarkan dalam pola keluarga tradisional, yaitu ayah bekerja dan ibu sebagai ibu rumah tangga. Maria hidup dalam keluarga yang terbuka, demokratis, dan disiplin.

Maria sejak kecil diwajibkan oleh ibunya untuk merenda dan membuat sesuatu untuk dibagikan kepada orang-orang miskin. Pengalaman inilah menjadi pembelajaran tentang kepekaan sosial yang ditanamkan oleh ibunya kepada maria. Selain itu, Maria kecil diwajibkan ibunya untuk membantu membersihkan lantai. Pengalaman ini yang kemudian dijadikan Maria sebagai dasar pembelajaran "kehidupan sehari-hari" dalam pendekatannya (Magini, 2013: 10).

\section{Latar belakang pendidikan Maria Montessori}

Pada tahun 1876 tepatnya saat Maria memasuki usia enam tahun, ia memasuki sekolah dasar di Roma. Sejak SD Maria sudah memiliki ketertarikan yang besar terhadap ilmu matematika. Maka, sewaktu SMA ia lebih memilih jurusan teknik. Maria menyelesaikan sekolah dasarnya pada pertengahan tahun 1881. Pada waktu itu, sekolah dasar berlangsung selama lima tahun dan sistempendidikan di Italia belummengenal sekolah menengah pertama. Waktu itu hanya ada sekolah kejuruan yang berlangsung selama tiga tahun. Sekolah kejuruan tersebut dapat disamakan dengan sekolah menengah pertama saat ini.

Kita dapat mengikuti alur pendidikan Maria Montessori berdasarkan sistem pendidikan Italia pada saat itu sebagai berikut: Pertama, tahun 1876/1877 hingga 1880/1881, Maria belajar di SD Via di San Nicolo dari Tolentino. Meskipun disebutkan bahwa sekolah dasar ditempuh selama5 tahun, terdapat data yang tidakjelas untuk tahun ajaran 1881/1882 dan tahun ajaran 1882/1883. Kedua, tahun 1883/1884 hingga 1885/1886, Maria belajar di sekolah kejuruan teknik Regia Scuola Tecnica Michelangelo Buonarotti. Ketiga, tahun 1886/1887 hingga 1889/1890, Maria belajar di akedemi kejuruan teknik Regio Istituto tecnico Leonardo da Vinci dan mengambil jurusan Ilmu Fisika dan Matematika. Keempat, tahun 1890/1891 hingga 1891/1892, Maria kuliah di Universitas La sapienza Roma, Fakultas Ilmu Pengetahuan Alam (IPA). Kelima, tahun 1892/1893 hingga 1895/1896, Maria beralih ke Fakultas Kedokteran dan menyelesaikan studinya (Magini, 2013: 14).

Pada saat Maria merasa tidak mengalami kesulitan dalam belajar dan selalu lulus ujian atau tes secara mudah, saat itulah ia mulai tertarik untuk belajar lebih serius. Ia sangat tertarik pada ilmu Matematika. Kadang-kadang, saat pelajaran teater di sekolah diam-diam Maria membawa buku matematikanya dan mempelajarinya dalam cahaya remang-remang. Ketertarikan yang besar terhadap ilmu matematika menyebabkan Maria meneruskan sekolahnya di sekolah kejuruan dasar teknik.

Memilih jurusan teknik tentu saja dianggap berlebihan oleh ayah Maria. Pada masa itu, wanita bergelar sarjana teknik belum pernah terpikirkan sama sekali, apa lagi ia berdarah bangsawan. Ambisi untuk mengambil sekolah jurusan teknik dinilai sangat tidak masuk akal karena sekolah teknik didominasi oleh laki-laki, dan tidak ada satupun siswa wanita di sekolah itu. Renilde mendukung Maria untuk berani melawan arus dan berjuang mewujudkan impiannya. Hal itu tampak setelah Maria lulus dari sekolah kejuruan dasar teknik. Maria ingin melanjutkan ke akademi kejuruan teknik, namun sekali lagi ia mendapat tantangan keras dari ayahnya. Berkat kegigihan dan dukungan kuat ibunya, akhirnya Maria diizinkan masuk Institut Ilmu Teknik dan lulus dengan nilai akhir 137 dari 150. Nilai Maria yang sangat bagus tersebut kian membuka jalannya ke Universitas.

Seiring berjalannya waktu, minat Maria terhadap ilmu teknik dan matematika berubah menjadi ketertarikan terhadap ilmu biologi. Oleh karena itu, setelah menyelesaikan sekolahnya di Institut Ilmu Teknik, Maria ingin mengambil kuliah di fakultas Kedokteran. Sekali lagi, keinginan Maria mendapat tantangan keras dari keluarganya, bahkan juga dari pihak universitas. Paradigma masyarakat pada saat itu, tidak mungkin seorang wanita mempelajari ilmu kedokteran, dan ilmu kedokteran hanya boleh dipelajari oleh laki-laki.

Jalan menuju Fakultas Kedokteran benar-benar tertutup rapat bagi Maria. Namun, Maria tidak kehilangan akal.niatnya untuk masuk ke fakultas Kedokteran ia tangguhkan sementara dan mengambil 
kuliah di Fakultas Ilmu Pengetahuan Alam (IPA). Tentu saja Renilde, ibu maria tidak tinggal diam. Maria dan ibunya berkisah banyak tentang kesulitan maria memasuki Fakultas Kedokteran kepada Antonio Stoppani yang pada waktu itu menjadi ilmuwan terkenal dari universitas Pavia dan Universitas di Milan. Antonio melayangkan surat pribadi kepada Paus dan ditembuskan kepada Universitas La Sapienza di Roma.

Pada akhirnya Maria diterima masuk ke Fakultas Kedokteran dengan mengikuti tes tertulis berbahasa Latin dan Italia. Pada waktu bersamaan, Paus Leo XIIImengeluarkan pernyataan bahwa profesi sebagai dokter merupakan profesi yang mulia bagi wanita. Sejak itu, protes masyarakat tentang kehadiran wanita yang ingin berprofesi sebagai dokter berhenti. Pada tanggal 10 Juli 1896, Maria lulus dari Fakultas Kedokteran dengan nilai luar biasa. Nilai maksimal untuk suatu kelulusan seharusnya adalah 100, Maria Montessori lulus dengan nilai 105. Itulah bukti bahwa Maria memang sangat luar biasa dengan kepekaan dan karismanya. Seperti ditulis Maria kepada seorang sahabatnya, "Aku terkenal bukan karena keahlianku atau kemampuan intelektualku. Aku terkenalhanya karena keberanianku menjadi berbeda dalambanyak hal. Ini seperti seseorang yang berharap dan selalu bisa mencapainya. Namun, untuk mencapai impian tersebut, diperlukan usaha dan pengorbanan yang besar" (Magini, 2013: 22).

\section{Corak dan Pengaruh Pemikiran Maria Montessori}

Pada tahun 1897, Maria Montessori memutuskan bergabung sebagai asisten sosial di rumah sakit Santo Spirito dibagian klinik psikiatri bersama dengan Giuseppe Montesano. (Giuseppe Montesano adalah dokter spesialis yang menangani penyembuhan anak-anak cacat mental. Ia telah banyak melakukan riset dibidang psikopatologi serta mendalami ilmu psikologi, khususnya tentang humor, perasaan, dan emosi). Tugas Maria adalah memberikan konsultasi dan terapi untuk pasien yang didiagnosa memiliki gangguan saraf dan menderita cacat mental. Salah satu tanggung jawab Maria adalah mengunjungi rumah sakit jiwa untuk menilik pasien yang masih memungkinkan untuk diterapi.

Pada saat berkunjung ke rumah sakit jiwa, Maria melihat sekelompok anak-anak tunagrahita dipenjarakan dan diperlakukan seperti narapidana. Melihat perlakuan tidak adil terhadap anak-anak tersebut dan mengamati berbagai kejadian di rumah sakit saat berkunjung, Maria tersentuh dan tergugah minatnya sebagai ilmuwan untukmencarikan solusi yang sesuai bagi mereka. Saat maria melihat sikap anak-anak tersebut diberi makan, tetapi mereka masih mengais remah-remah makanan yang jatuh di lantai, maria merasakan bahwa anak-anak tersebut sebenarnya tidak lapar secara fisik, melainkan secara mental. Mereka tidak memilki apapun yang bisa disentuh, dipelajari dengan tangan dan mata mereka. Mereka hanya dikurung di ruangan yang membosankan tanpa diberi kegiatan atau sarana untuk beraktivitas. Hal tersebut menjadi awal Maria terjun dalam dunia anak-anak.

Ketertarikan profesional pertama Maria adalah tentang keterbelakangan mental. Dia merasa bahwa anak-anak terbelakang ini bisa diajar layaknya anak-anak normal jika dapat menemukan metode yang benar. Dia membaca banyak literatur tentang topik ini dan menemukan bahwa intuisinya telah menuntun dia kepada pemikiran para pendidik sebelumnya seperti Itard (Dokter Psikiatri lulusan tahun 1800), Seguin (Murid Itard), dan Frobel (Tokoh Pendidik dari Jerman pengikut Pestalozzi). Menurut para pendidik ini, kita tidak bisa begitu saja mengajar anak-anak yang terbelakang mental dengan hal-hal yang kita anggap perlu mereka ketahui, seperti membaca dan menulis. hal ini hanya akan membuat mereka frustasi karena anak-anak ini secara intelektual belum siap untuk belajar pada tingkatan tersebut. Jadi kita harus mengamati lebih dulu anak-anak tersebut dan memperhatikan dengan seksama kecenderungan alamiah dan ketertarikan spontan mereka (Crain, 2007: 98).

Maria mengikuti pendekatan Serguin ini, menggunakan banyak materi pendekatannya, dan mencoba materinya sendiri. Dia sangat gembira waktu melihat pendekatan ini berhasil sehingga mulai mengajarkan mereka hal-hal yang lebih sulit, yaitu membaca dan menulis dengan cara yang sama. Karena anak-anak yang terbelakang tampaknya dapat belajar sangat baik dengan menyentuh dan merasakan objek-objek, Maria memberi merekahuruf-huruf dari kayu yang harus mereka susun dengan tangan berulang-ulang. Dengan metode-metode serupa dia sanggup mengajar kebanyakan anak yang seperti ini membaca dan menulis layaknya anak normal di usia mereka.

Selanjutnya, Maria bekerja sama dengan Sciamanna, De Sanctis, dan Sergi mencoba meneliti anak-anak tunagrahita berdasarkan teori yang dikemukakan oleh Pinel, Itard, dan Seguin serta melahap 
habis informasi tentang solusi-solusi yang diberikan oleh pendahulunya dalam mendekati anak. mulailah proses pemikiran Maria berkembang seiring dengan pengalaman hidupnya sebagai dokter. Ia mengkombinasikan pemikiran Froebel dalam mendekati anak, pemikiran Itard dan Seguin pada anakanak bisu-tuli, dan juga menggunakan pemikiran berdasarkan teknik antropologis (Magini, 2013: 28).

Pendekatan antropologis yang diperoleh Maria saat masih kuliah dipengaruhi oleh dosennya, Cesare Lombroso. Lombroso mengawali kariernya sebagai seorang dokter dan ahli bedah di bagian kriminologi, kemudian ia menjadi profesor kriminal antropologi di Universitas Turin pada tahun 1906. lombroso meyakini bahwa penjara dan rumah rehabilitasi tidak akan pernah bisa menyembuhkan penyakit kriminalitas. Para residivis tingkat tinggi tidak mungkin disembuhkan dan menyingkirkan mereka dari masyarakat hanya berdampak penurunan tingkat kriminalitas saja, tetapi tidak akan bisa menyembuhkan masyarakat yang sakit secara umum. Satu-satunya cara untuk mengobati masyarakat yang sakit adalah melalui pendidikan dan latihan sejak kecil (Magini, 2013: 29).

Pada tahun 1910, Montessori telah memperoleh pengakuan sebagai seorang pendidik inovatif yang signifikan ditanah kelahirannya Italia, dimana dia memimpin sebuah sekolah percontohan dan sebuah institut pelatihan bagi para direktris. Reputasi Montessori yang semakin tinggi menarik perhatian dunia pendidikan di negara-negara Eropa lain dan di Amerika Utara, khusunya di Amerika Serikat. Selanjutnya Montessori mengontrol secara langsung pelatihan para pendidik Montessori untuk mencegah penyimpangan dari metodenya sebagaimana yang dia pahami. Dia akan mengontrol produksi dan distribusi dari bahan-bahan dan perlengkapan Montessori (Montessori, 2013: 33).

\section{Gagasan dan Peran Pemikiran Maria Montessori}

Dari pekerjaan yang berhubungan dengan anak-anak yang menyandang cacat mental, Maria Montessori banyak menemukan ide dan gagasan bagi pendidikan untuk anak normal, lebih khsusus lagi diperuntukkan bagi anak dibawah lima tahun. Dalam bukunya William Crain (2007), pada tahun 1907 Maria mengambil tanggung jawab untuk mendidik anak-anak yang tinggal di perumahan kumuh San Lorenzo, salah satu pinggiran kota Roma. Disana dia mendirikan sekolah pertamanya untuk mendidik lebih dari 50 anak-anak yang sangat miskin, putra-putri para pekerja yang dipecat, pengemis, pelacur, dan penjahat jalanan.

Sekolah ini dinamainya Casa Dei Bambini artinya Rumah Anak-Anak. Maria terus mengembangkan ide-ide dan teknik-tekniknya, dan dia begitu berhasil sehingga sehingga pada tahun 1913 menjadi salah satu wanita yang paling terkenal di koran-koran. Tampaknya ide-idenya telah mengubah arah pendidikan di seluruh dunia. Secara perlahan pemikirannya berkembang di beberapa negara Eropa dan berbagai penjuru dunia lainnya, tetapi ada juga yang menentang pemikirannya. Pada tahun 1915 semasa perang dunia pertama Maria mendirikan sekolah Word Exhibition di San Fransisco, Amerika. Ia juga mendirikan gerakan Montessori di India yang terus berkembang hingga saat ini (Sujiono, 2009: 107).

Maria Montessori telah merumuskan sejumlah teori mengenai belajar pada masa usia dini. Menurut Yuliani (2009) beberapa pandangan yang dan prinsip Montessori dalam mengembangkan pendidikan anak usia dini dapat dicermati dari beberapa falsafah berikut ini: (1) Anak usia dini tidak seperti orang dewasa, mereka terus menerus berada dalam keadaan pertumbuhan dan perubahan, dimana pertumbuhannya sangat dipengaruhi oleh lingkungan; (2) Anak usia dini senang sekali belajar 'selalu ingin tahu dan mencoba, Tugas orang dewasa adalah mendorong, memberi kesempatan belajar dan membiarkan anak belajar sendiri; (3) Pikiran anak yang masih kecil mempunyai kemampuan besar untuk menyerap berbagai pengalaman. Masa yang paling penting adalah masa pada rentang usia sejak lahir sampai umur 6 tahun; (4) Anak usia dini menyerap hampir semua yang dipelajarinya dari lingkungan; (5) Anak belajar banyak melalui gerakan-gerakan, ia membutuhkan kesempatan untukbergerak, bereksplorasi, belajar melalui alat inderanya; (6) Anak melewati masa-masa tertentu dalam perkembangannya dan lebih mudah untuk belajar, yang disebut dengan periode sensitive untuk belajar; (7) Semakin banyak kesempatan anak mengirimkan rangsangan-rangsangan sensoris ke otak, maka semakin berkembang kecerdasannya; (8) Anak paling baik belajar dalam situasi kebebasan yang disertai disiplin diri. Anak harus bebas bergerak dan memilih kegiatan yang disenanginya didalam kelas dengan disertai disiplin diri; (9) Orang dewasa khususnya guru tidak boleh memaksakan anak untuk belajar sesuatu, dan tidak boleh mengganggu apa yang sedang dipelajari anak; (10) Anak harus belajar sesuai dengan taraf 
kematangannya, tanpa paksaan untuk menyesuaikan atau menjadi sama dengan anak lain; (11) Anak mengembangkan kepercayaan pada dirinya bila ia berhasil melaksanakan tugas-tugas sederhana; (12) Bila anak diberi kesempatan untuk belajar pada saat sudah siap 'matang' untuk belajar, dia tidak saja akan dapat meningkatkan kecerdasannya, tetapi juga akan merasakan kepuasan, menambah kepercayaan diri dan keinginan untuk belajar lebih banyak.

William Crain (2007) menjelaskan bahwa komponen utama teori Montessori adalah konsep periode-periode kepekaan. Periode-periode kepekaan (sensitive periods) mirip dengan periode-periode kritis; secara genetis mereka sudah diprogram untuk memblokir waktu sehingga pada waktu tertentu anak begitu ingin dan mampu menguasai tugas-tugas tertentu. Dalam bukunya Crain menjelaskan satu persatu kerja dalam periode-periode Montessori tersebut, diantaranya adalah: 1). Peride kepekaan akan keteraturan, 2). Periode kepekaan akan detail, 3). Periode kepekaan bagi penggunaan tangan, 4). Periode kepekaan untuk berjalan, 5). Periode kepekaan terhadap bahasa.

Ada beberapa hal yang menjadi karakteristik kelas Montessori. Pertama, pengelompokkan bauran usia biasanya usia 3, 4, dan 5 tahun digabungkan. Sebagai pula usia 6, 7, dan 8 tahun dan seterusnya. Kedua, pengaturan ruangan dengan rak-rak rendah terbuka berisi banyak materi yang diatur dengan cermat yang bisa dipilih oleh anak-anak. Ketiga, ruang terbuka dilantai membuat anak-anak bisa bekerja di lantai. Keempat, Jumlah rak untuk memuat materi Montessori yang diperlukan lebih banyak dari yang biasanya terlihat pada model pendidikan lainnya. Kelima, sikap bekerjasama alih-alaih persaingan dalam menyelesaikan tugas (Roopnarine dan Johnson, 2011: 382).

Pada akhir 1950-an, gerakan kontemporer Montessori amerika dimulai dalam bentuk serangkaian sekolah swasta yang hampir seluruh nya melayanimasyarakat kelas menengah. Banyak dari sekolah usia dini ini didirikan oleh para orang tua. Pada 1959 didirikan American Montessori Society (AMS) (Masyarakat Montessori Amerika). Pendirinya, Nancy McCormick Rambusch, dimana dia menegaskan bahwa tidak hanya adopsi tapi adaptasi metodeMontessori juga penting agar bisa diterjemahkan dan “dinaturalisasikan"kedalam budaya Amerika yang beragam (Roopnarine dan Johnson, 2011: 381).

Dalam perkembangannya, badan-badan pendidikan yang menamakan dirinya menganut falsafah Montessori, dikenal ada dua macam pengkategorian, yaitu badan pendidikan yang memiliki franchise Montessori dan badan pendidikan yang hanya mengadopsi pemahaman teori dasar Montessori. Badan-badan yang memiliki franchise Montessori terdapat aturan penggunaan metode yang sangat ketat dan baku. Penggunaan alat peraga, misi dan visi sekolah, serta pendekatan pengajarannya di sekolahsekolah dengan kategori ini benar-benar dibawah kontrol kualitas pemegang lisensi Montessori (Harjaningrum, 2007: 55).

Sedangkan pada golongan yang hanya mengadopsi pemahaman dasar teori Montessori, maka sekolah-sekolah tersebut tidak boleh menggunakan nama Montessori dibadan pendidikannya. Namun biasanya pada penjelasan misi, visi, dan pendekatannya, akan terdapat jabaran tentang metode Montessori yang digunakan. Dengan pemakaian metode ini, maka setiap anak dilihat sebagai individu, sehingga pendekatan secara individu harus dilakukan seoptimal mungkin dalam lingkungan natural si anak. penggunaan metode ini juga membawa konsekuensi bahwa anak memiliki hak untuk belajar sesuai dengan cara dan metode yang diinginkannya (Harjaningrum, 2007: 56).

Secara metode pembelajaran, Suyadi dan Ulfah (2013: 99-101) membagi esensi metode pendidikan Montessori dalam empat hal: (1) Semua pendidikan adalah pendidikan diri sendiri (child centred). Menurut Montessori, segala bentuk keberhasilan dan perkembangan jasmani dan rohania anak adalah hasil dari belajarnya sendiri. Ia tumbuh begitu cepat laksana anak panah yang melesat. (2) Kebebasan. Dalam proses belajar-mengajar anak didik harus diberi kebebasan seluas-luasnya. Guru tidak boleh melaksanakan materi tertentu kepada anak, walaupun materi tersebut sangat penting. Tugas guru lebih bersifat "pasif" dan hanya sebatas memberi stimulasi agar anak didik tertarik dengan stimulasinya tersebut. sehingga konsekuensinya di kelas sekolah Montessarian tidak mungkin anak melakukan permainan yang sama. (3) Ketertiban. Ketertiban dalam pandangan Montessori adalah bukan aturan ketat yang seringkali membelenggu kebebasan anak didik. Tertib bukan pula ditegakkan dengan hukuman apalagi ancaman tidak naik kelas. Tertib dalam pandangan Montessori adalah "seperangkat aturan" untuk menunjang lancarnya proses belajar secara bebas. (4) Pengembangan indera. Menurut Montessori, 
masuknya segala pengertian dan konsep-konsep dalam pikiran anak adalah indera semata. Dalam hal ini, Montessori menempatkan indera sebagai "gerbang" jiwa ana. Jadi, segala hal yang diajarkan kepada anak harus berupa aktivitas secara konkret dan jelas. Atas dasar inilah muncul berbagai pandangan tentang imajinasi dalam pandangan Montessori.

Untuk menjangkau audien yang lebih luas, Montessori menggunakan dua cara utama untuk menyebarkan metodenya: ceramah dan penerbitan. Sebagai seorang profesor Montessori menjadi dosen yang ahli dan dia menggunakan ceramah didepan umum untuk menyebarkan metodenya. Montessori juga ahli dalam menggunakan penerbitan untuk menyebarkan ide-idenya baik kepada kalangan pendidik maupun kepada kalangan publik.

\section{Rekonstruksi Metode Montessori}

Maria Montessori termasuk tokoh peletak dasar pendidikan prasekolah yang meyakini bahwa pendidikan dimulai sejak anak lahir. Tahun-tahun pertama kehidupan anak merupakan masa-masa sangat formatif dan merupakan masa yang paling penting baik fisik maupun mental. Bayi yang masih kecil perlu dikenalkan pada orang-orang dan suara-suara, diajak bermain dan bercakap-cakap agar anak dapat berkembang menjadi anak normal yang bahagia.

Pada tahun-tahun awal kehidupan seorang anak mempunyai masa peka (sensitive periods). Hal tersebut dapat digambarkan sebagai satu situasi atau waktu siap berkembangnya pembawaan atau potensi yang dimiliki anak. Potensi akan mati dan tidak akan muncul lagi apabila tidak diberikan kesempatan untuk berkembang tepat pada waktunya. Sedangkan dasar pendidikan Montessori yaitu penghargaan terhadap anak, absorbent mind (pemikiran yang cepat menyerap), sensitive periods (masa peka), penataan lingkungan sesuai dengan karakteristik dan kebutuhan anak, pedosentris (pendidikan diri sendiri) dan kebebasan.

Pada umumnya dikatakan bahwa anak-anak tampak tumbuh dalam dua tahapan utama. Mereka mulai sebagai bayi yang dikaruniai dorongan naluriah, yang secara berangsur-angsur mereka belajar, dengan lebih kurang berhasil, untuk mengendalikannya. Tahapan pertama ini berakhir pada usia 11 sampai 14 tahun, mereka sekali lagi menunjukkan banyak karakteristik masa kanak-kanak awal. Selanjutnya mereka memasuki apa yang disebut secara populer sebagai "masa kanak-kanak kedua" yaitu masa pubertas (Hughes, 2015: 382-383).

Karakteristik bimbingan dan konseling anak usia dini berdasarkan Metode Montessori adalah melalui pengkondisian, agar pendidik dan pembimbing lebih efektif dalam melakukan pembelajaran pada anak. Bagaimanapun kepribadian anak usia dini akan sangat dipengaruhi oleh faktor internal (dari dalam diri anak itu sendiri) dan factor eksternal (pengaruh lingkungan). Guru dan pendamping pada suatu lembaga PAUD harus membantu anak mengembangkan segala potensi yang ada dalam diri anak dan mengembangkan seluruh aspek perkembangannya. Guru dan pendamping berperan tidak hanya sebagai pendidik melainkan sebagai pembimbing yang dapat memfasilitasi tumbuh kembang anak secara optimal dalam semua aspeknya.

Jika merujuk pada dasar pendidikan Montessori, maka ciri bimbingan dan konseling bagi anak usia dini harus memenuhi keriteria sebagai berikut: 1). Proses bimbingan dan konseling harus disesuaikan dengan masa peka anak yang harus dimanfaatkan dan jangan sampai terlewatkan sesuai potensi yang ada dalam diri anak; 2). Pelaksanaan bimbingan terintegrasi dengan kegiatan bermain anak; 3). Pemanfaatan lingkungan sebagai sumber belajar menjadi pola bimbingan dan konseling anak disesuaikan dengan kebutuhan lingkungannya; 4). Adanya keterlibatan orang tua dalam pelaksanaan bimbingan dan konseling anak, karena orang tua merupakan orang yang paling dekat dengan anak; 5). Adanya bimbingan belajar dari guru yang memeberikan kebebasan kepada anak dalam menentukan kegiatan atau jenis mainnya; dan 6). Adanaya perencanaan layanaan bimbingan dan konseling anak yang terjadwal dan berkala sebagai bagian dari pelaporan perkembangan anak dari Satuan PAUD kepada orang tua.

\section{SIMPULAN}

Prinsip-prinsip metode Montessori dalam bimbingan dan konseling bagi anak usia dini secara umum adalah bahwa anak dilihat sebagai individu yang harus dikembangkan potensinya seoptimal mungkin dalam lingkungan si anak. Kita sebagai orang dewasa tidak bisa menyepelekan dan meremehkan 
kemampuan anak, sehingga anak memilki hak untuk belajar sesuai dengan cara dan metode yang diinginkannya. Guru dan pembimbing anak usia dini harus mampu memfasilitasi anak belajar sesuai dengan metode yang diinginkannya dan jenis main atau kegiatan yang diinginkannya.

Selain itu dalam melaksanakan program bimbingan dan konseling bagi anak usia dini diperlukan hal-hal sebagai berikut, yaitu: tujuan yang hendak dicapai, personal yang terlibat di dalamnya, kegiatan-kegiatan yang dilakukan, sumber-sumber yang dibutuhkan, cara melakukannya serta alokasi waktu kegiatan.

\section{DAFTAR PUSTAKA}

Crain, William. 2007. Teori Perkembangan Konsep dan Aplikasi. Yogyakarta: Pustaka Pelajar.

Daryanto dan Mohammad Farid. 2015. Bimbingan Konseling; Panduan Guru BK dan Guru Umum. Yogyakarta: Penerbit Gava Media.

Fiah, Rifda El. 2019. Bimbingan dan Konseling Anak Usia Dini. Cet-2. Depok: Rajawali Pers.

Harjaningrum, Agnes Tri. 2007. Peranan Orang Tua dan Praktisi Dalam Membantu Tumbuh Kembang Anak Berbakat Melalui Pemahaman Teori dan tren Pendidika., jakarta: Prenada Media Group.

Hughes, A.G. dan E.H. Hughes. 2015. Learning and Teaching. Terj. SPA Teamwork Yogyakarta \& Purwanto. Psikologi Pembelajaran; Teori dan Terapan. Bandung: Penerbit Nuansa Cendekia.

Iskandar. 2008. Metodologi Penelitian Pendidikan dan Sosial. Jakarta: Gaung Persada Press.

Kahfi, Muhammad Alim. "Dimensi Kecerdasan Aq (Adversity Quotient) Anak dalam Perspektif Kurikulum 2013 Pendidikan Anak Usia Dini." Indonesian Journal of Early Childhood: Jurnal Dunia Anak Usia Dini 2.2 (2020): 65-87.

Magini, Agustina Prasetyo. 2013. Sejarah pendekatan Montessori. Yogyakarta: KANISIUS.

Monks, F.J. dan A.M.P. Knoers. 2006. Ontwikkelings Psychologie; Inleiding tit de verschillende deelgebieden. Terj. Siti Rahayu Haditono. Psikologi Perkembangan; Pengantar Dalam berbagai Bagiannya. Cet. 16. Gadjah Mada University Press.

Montessori, Maria. 2013. Metode Montessori. Terj. Ahmad Lintang Lazuardi. Yogyakarta: Pustaka Pelajar.

Roopnarine, Jaipaul L. \& James E. Johnson. 2011. Pendidikan Anak Usia Dini Dalam Berbagai Pendekatan. Jakarta: Kencana Prenada Media Group.

Sujiono, Yuliani Nurani. 2009. Konsep dasar Pendidikan Anak Usia Dini, Jakarta: Indeks.

Suyadi dan Maulidya Ulfah. 2013. Konsep Dasar PAUD. Bandung: Remaja Rosdakarya. 